\title{
Morphological and phylogenetic characterization of Fusarium Link.
}

\section{Leonardo de Jesus Machado Gois de Oliveira ${ }^{1}$, Antonia Alice Costa Rodrigues* ${ }^{1}$, Erlen Keila Candido e Silva ${ }^{1}$, Anna Christina Sanazário de Oliveira ${ }^{1}$, Maria Claudene Barros ${ }^{2}$, Elmary da Costa Fraga ${ }^{2}$ Ivaneide de Oliveira Nascimento ${ }^{3}$, Maria Rosangela Malheiros Silva ${ }^{1}$}

\author{
${ }^{1}$ Programa de Pós-graduação em Agroecologia, Centro de Ciências Agrárias/CCA, Universidade Estadual do Maranhão, \\ Cidade Universitária Paulo VI. São Luís/MA, CEP. 65055-310, Brasil \\ ${ }^{2}$ Programa de Pós-graduação em Biodiversidade, Ambiente e Saúde, Centro de Estudos Superiores de Caxias - CESC, \\ Caxias/MA, CEP: 65.604-380, Brasil \\ ${ }^{3}$ Universidade Estadual da Região Tocantina do Maranhão, Brasil
}

*Corresponding authors: aacrodrigues.uema@gmail.com

\begin{abstract}
Identification of Fusarium isolates in a sample at the species level is an important and difficult task because many Fusarium species have similar morphological characteristics. The phylogenetic relations of species have been applied in Fusarium systematic and may solve taxonomic difficulties. The aim of the present study is to characterize pathogeny of Fusarium isolates through morphological analysis (concept of morphological species) associated with symptoms in hosts together with phylogeny analysis (concept of phylogenetic species) using internal transcribed spacer region (ITS) of ribosomal DNA for species identification. For the morphological characterization, Fusarium isolates were grown in PDA culture medium. Then, they were classified based on colony color and the microconidial, macroconidial and chlamydospore structures. The isolates were characterized molecularly by amplifying and sequencing the ITS region of the ribosomal DNA. The sequences generated were compared with those placed in the Genbank and Maximum Likelihood phylogenetic trees were constructed. Out of 14 isolates characterized morphologically and molecularly, five isolates were grouped in the Gibberella fujikuroi species complex in the Liseola section, seven presented characteristics of species from the Elegans section within the $F$. oxysporum species complex and two isolates presented characteristics of the section Gibbosum species complex in the $F$. incarnatum-equiseti species complex. Thus, seven isolates (section Elegans) belonged to the species $F$. oxysporum, two isolates (section Gibbosum) to the species F. equiseti. However, the ITS region of the ribosomal DNA did not provide sufficient evidence to define the species of $G$. fujikuroi species.
\end{abstract}

Keywords: Phylogeny, Morphology, Fusarium oxysporum, F. equiseti, Gibberella fujikuroi.

Abbreviations: ITS_Internal Transcribed Spacer. GFSC_Gibberella fujikuroi species complex, FGSC, FOSC, Fusarium oxysporum species complex, FIESC, Fusarium incarnatum-equiseti species complex, FSSC, Fusarium solani species complex ICN_ International Code of Nomenclature for algae, fungi, and plants

Introduction

The Fusarium species are commonly associated to many diseases of economically important crops and to mycotoxin producers (Summerell, 2019). The types of diseases induced by this species are varied, as well as their severity, which can include root or stem rot, canker, wilt, fruit or seed rot and leaf diseases. However, other habitats and hosts, including natural ecosystems and diversified agroecosystems, clinical and veterinary samples (O'Donnell et al. 2016; Papizadeh et al., 2018) and insects (Aoki et al., 2019; Santos et al., 2019) have also been shown to be important sources for the investigation of Fusarium species.

Therefore, identification of Fusarium isolates in sample of diseased plants, animal, insects generally at species level, is an important and difficult task in many plant diagnosis laboratories (Aoki et al., 2014; Stepień et al., 2013). Given these circumstances, it is critically important that Fusarium has a stable taxonomy with well-defined generic and species concepts that allows practitioners diagnosing diseases, identifying these fungi, and developing management strategies to make decisions about the identity of the species (Summerell, 2019).

The difficulty of studying these species is mainly due to their similar morphology and existence of different biological groups that include endophytes, saprophytes, and plant pathogens, and also human pathogens (Imazaki and Kadota, 2015; Moussa et al., 2017; Nayaka et al., 2009; Zarrin et al., 2016), which does not allow the precise resolution for adequate identification of new species (Choi et al., 2017). 
As an alternative, the difficulties of morphological (morphological species concept) identification of the Fusarium, the molecular tools (phylogenetical species concept) have been used for precise identification of species ( $O^{\prime}$ Donnell et al., 2018). Therefore, the phylogenetic studies have been utilized in Fusarium systematic and can be used to solve taxonomic difficulties by providing reliable pathogen identification (O'Donnell et al., 2015)

Fusarium includes 300 phylogenetically different species that were discovered via molecular phylogeny. However, most of the species have not yet been described formally $\left(\mathrm{O}^{\prime}\right.$ donnell et al., 2018).

Within the large genus of Fusarium, it has become customary to cluster closely related sibling species or lineages from littleto no-morphological differences in so-called species complexes (Van Diepeningen and Hoog, 2016). The term species complex is not well defined but usually implies a grouping of species with shared morphological characteristics and phylogenetic markers, and some level of cryptic speciation the ICN (Al-Hatmi et al., 2019). There are 23 species complexes that provide a mechanism to introduce researchers to the taxonomy of Fusarium and allow them to better comprehend the diversity of species within the genus (Summerell, 2019). The generic and species concepts in Fusarium have endured significant changes. Currently, Fusarium has been distributed within a species complex (Sandoval-Denis et al., 2018).

In addition to these results, recent studies have shown that most of the plant pathogens of this genus are grouped in species complexes such as the Fusarium fujikuroi species complex (FFSC), Fusarium oxysporum species complex (FOSC), Fusarium incarnatum-equiseti species complex (FIESC), Fusarium solani species complex (FSSC) (Leyva-Madrigal et al., 2015; Epstein et al. 2017; Maryani et al., 2019; Papizadeh et al., 2018)

Among the regions of the ribosomal cistron, the internal transcribed spacer (ITS) region has the highest probability of successfully identifying a large variety of fungi, with the difference in barcodes more clearly defined between intra and interspecific variations in different variations including the genus Fusarium. The recognition of ITS as the official DNA barcode marker for fungi represents a noteworthy advance, which has greatly benefited the research community (Zarrin et al., 2016; Schoch et al., 2012; Nadarajah et al., 2015).

Thus, the aim of the present study was to characterize pathogenic Fusarium isolates from Brazil through morphological analysis (concept of morphological species) associated with symptoms in hosts such as vascular wilting, rotting (fruits, stems, and leaves), and insect colonization together with phylogenetic analysis (concept of phylogenetic species) of the internal transcribed spacer region (ITS) of ribosomal DNA for species identification

\section{Results}

\section{Morphological characterization of the Fusarium isolate}

The morphological characterization showed a range of variability in species that were observed pathogenic to plants and insects.

The macromorphological aspect of the coloring of the isolate colonies was separated into five groups. The first group had completely pink coloring. This predominant pink color was observed in the following isolates (MGSS 15, MGSS 42, MGSS 118, MGSS 141, MGSS 149, MGSS 182, MGSS 183), the second group presented pink colored colonies with pale borders (MGSS 54, MGSS 68, MGSS 157), the third group was formed by purple colored colonies (MGSS 09, MGSS 14), the fourth group was formed by a colony a salmon colored colony (MGSS 61 ) and the fifth group was formed by a burnt yellow colored colony (MGSS 138) (Fig. 1 and Table 4).

The micromorphological evaluation separated the isolates into six groups. Group 1 (Macroconidia 2- 5 septa, presence of Microconidia, Short Monophialides, presence of Chlamydospore): MGSS 14, MGSS 15, MGSS 42, MGSS 182, MGSS 183; Group 2 (Macroconidia 2- 5 septa, presence of Microconidia, Short Monophialides, absence of Chlamydospore): MGSS 09, MGSS 118; Group 3 (Macroconidia 2-5 septa, presence of Microconidia, Monophialides and polyphialides, absence of Chlamydospore): MGSS 54, MGSS 61, MGSS 68; Group 4 (absence of Macroconidia, presence of Microconidia, Monophialides and polyphialides, absence of Chlamydospore): MGSS 141, MGSS 157; Group 5 (Macroconidia 3-7 septa, absence of Microconidia, Monophialides, presence of Chlamydospore): MGSS 138; Group 6 ((Macroconidia 3-7 septa, absence of Microconidia, presence of Mesoconidia, Monophialides, presence of Chlamydospore): MGSS 149 (Table 2).

Thus, according to the morphological characteristics and associated to the types of symptoms caused by the fungus plant pathogens, the following strains were classified in Fusarium oxysporum (section Elegans): MGSS 09, MGSS 14, MGSS 42, MGSS 118, MGSS 182 and MGSS 183 that were associated to vascular darkening and wilting in the host species (Fig. 2).

The isolates MGSS 09, MGSS 14, MGSS 15, MGSS 42, MGSS 118, MGSS 182, MGSS183 presented characteristics of the species $F$. oxysporum with aseptate microconidia formed in false heads in short monophialides and chlamydospores formed individually, in pairs, grouped in short chains, straight or slightly curved macroconidia that presented 3-5 septa.

The colony coloring of the isolates of the $F$. oxysporum species also presented different shades. For example, the isolates MGSS 14 and MGSS 183 showed different colors.

The isolates MGSS 138 and MGSS 149, from fruits of the Carica papaya and leaves of Lactuta sativa were classified as $F$. equiseti in the Gibbosum section (Fig. 3).

The isolates MGSS 54, MGSS 61, MGSS 68, MGSS 141, MGSS 157 presented macro and micromorphological characteristics similar to the species belonging to the Gibberella fujikuroi species complex. The pigmentation of the colony coloring varies from pink to salmon, thin, straight macroconidia with 3 to 5 septa or septa absence, oval, elliptic shaped microconidia with no or one septum, presence of conidia in false heads or in chains and absence of chlamydospores.

The strains MGSS 68 and MGSS 54 that were associated to exudation symptoms in Ananas comosus shoots and fruits was classified as $F$. guttiforme (Liseola section). The isolate MGSS 15 was also associated to gum exudation, but some micromorphological characteristics placed it in the Elegans section, such as chlamydospore production (Fig. 4).

The isolates MGSS 141 and MGSS 157 presented similar morphological characteristics and came from Hibiscus sabdariffa stem rot (Fig. 5). 
Table 3 shows a summary of the association of the morphological characterization and symptomological aspects observed in hosts. Out of the 14 isolates, five isolates were grouped morphologically in the Gibberella fujikuroi species complex in the Liseola section, seven presented characteristics of the species of the Elegans section in the Fusarium oxysporum species complex (FOSC) and two isolates presented characteristics of the Gibbosum section in the $F$. incarnatum-equiseti species complex (FIESC).

\section{Molecular characterization of the Fusarium spp. isolates}

The phylogenetic tree was constructed with 43 nucleotide sequences and 14 isolate sequences identified morphologically as belonging to the genus Fusarium.

The phylogenetic analysis showed the formation of two groups. The first group consisted of the Liseola and Elegans section and the second group of species in the Gibbosum section.

The group with the species from the Liseola and Elegans section presented a branch supported by $89 \%$ of bootstrap. In the Liseola section, the evolutionary history of the ITS gene for the isolates MGSS 157, MGSS 141, MGSS 61, MGSS 54 and MGSS 68 showed that they grouped with lines of the $G$. fujikuroi species complex (GFSC). G. fujikuroi is a fairly diverse species complex of approximately 50 lines where many species are unknown (O'Donnell et al., 2013). In the Elegans section, seven isolates (MGSS 118, MGSS 09, MGSS 15, MGSS 183, MGSS 182, MGSS 14, MGSS 42) clustered with the $F$. oxysporum lines. The group of the Gibbosum section presented two well-defined clades, the first clade was highly significant with 99\% bootstrap grouped the isolates MGSS 138 and MGSS 149 with the F. equiseti lines (Fig. 6).

The 14 Fusarium isolates were identified morphologically and the species determination confirmed by PCR primers specific for ITS gene sequencing. The nucleotide sequences were subsequently placed in the NCBI/Genbank database (Table 1). The information obtained in this research based on the ITS gene is adequate to understand the evolutionary relationships of the Fusarium populations where the isolates were separated into three species complexes as follows: G. fujikuroi species complex (GFSC), F. oxysporum species complex (FOSC) and $F$. incarnatum-equiseti species complex (FIESC).

\section{Discussion}

The survival resistance structure observed in the isolates MGSS 15, MGSS 138, MGSS 149 (individual chlamydospores), MGSS 42 (individual and in pairs) MGSS 182 (clustered or in short chains) and MGSS 183 may remain resting in substrates or the soil for many years when conditions are unfavorable, so that the pathogen is able to persist in the environment until there are favorable conditions when it becomes active, returning to cause the disease in the susceptible hosts (Fischer and Rezende, 2016).

The morphological characteristics of isolates of the genus Fusarium have been investigated in several culture media as such as de agar clove - CLA (Ramdial et al., 2017), synthetic nutrient agar - SNA (Figueroa-rivera et al., 2010; Moussa et al., 2017) and Potato-Dextrose-Agar - BDA (Akbar et al., 2018). The use of the previously mentioned referred culture media is indicated because they are standard media for genus identification and according to Leslie and Summerell (2006).

The colonies showed variation in the pigmentation of the different isolates cultured on PDA culture medium that was expected, because they are different species of the genus. Thus, the micromorphology observation also showed variation for presence or absence, shape and macroconidia and microconidia septa number.

The characteristics presented in the isolates MGSS 09, MGSS 14, MGSS 15, MGSS 42, MGSS 118, MGSS 182, MGSS183 are fundamental for correct identification of the species $F$. oxysporum. The variation in macromorphological coloring characteristics within the species presented in the the isolates MGSS 14 and MGSS 183 was also reported by Teixeira et al. (2017).

The isolates MGSS 138 and MGSS 149 presented macroconidia with 5-7 septa and coloring that ranged from burnt yellow (MGSS 138) to pink (MGSS 149) in PDA culture medium. One isolate presented septate mesoconidia (MGSS 149). Both isolates formed individual chlamydospores but no microconidia (absence) that are typical characteristics of the species reported by the authors Bonde et al. (2014) and Ramdial et al., (2017).

F. esquiseti is easily confused morphologically with the species F. compactum (brown pigmented isolates), F. semitectum, and F. scirpi. F. compactum and $F$. equiseti which are distinguished based on their growth rate in PDA (Leslie and Summerell, 2006). Regarding the hosts, this species has been associated to diseases in different crops such as rice (Nadarajah et al., 2015), fruit and vegetables (Bonde et al., 2014), wheat (Castellá and Cabañes, 2014).

Regarding the Gibberella fujikuroi species complex, there are a few morphological traits to differentiate species within complex the species as stated by Hsuan et al. (2011) who observed that isolates classified morphologically as $F$. subglutinans at first were later called classified as $F$. sacharri based on sequences of the gene TEF- $1 \alpha$ (elongation factor 1$\alpha)$.

The occurrence of Fusarium disease in $\mathrm{H}$. sabdariffa has been reported in countries on the African continent, in Nigeria by Amusa et al. (2005) and Agbenin and Ogunlana (2006), in Egypt by Hassan et al. (2014). With that, it can be said that the isolates MGSS 141 and MGSS 157 which had similar morphological characteristics are originated from this disease. The isolate MGSS 61 pathogenic to black fly in citrus Aleurocanthus woglumi, presented characteristics of the $G$. fujikuroi species complex in the Liseola section and classified as F. proliferatum and differentiated from $F$. verticillioides by the presence of mono and polyphialides. Other authors identified species of this complex that were associated to insects such as the species F. verticillioides (Pelizza et al., 2011) and F. fujikuroi (Sharma et al., 2018).

Some studies have been carried out to define the species level of the genus Fusarium using the ITS region of the rDNA and this region was shown adequate for reliable identification of the fungus isolates of this genus. Zarrin et al. (2016), Yuan et al. (2013) and Nadarajah et al. (2015) also differentiated the Fusarium species with medical and agricultural importance using the gene of the ITS region. 
Table 1. Fusarium sequences used for phylogenetic analysis of the rDNA gene ITS.

\begin{tabular}{|c|c|c|c|}
\hline Species & Strain Number & Host/ Substrate & Code in Genbank \\
\hline Fusarium circinatum & 6DTJF01 & Root of aquatic plant & KT184799 \\
\hline Fusarium dimerum & CBS 116527 & - & EU926284 \\
\hline Fusarium equiseti & MGSS 149 & Lactuca sativa- Leaf & MF449200 \\
\hline F. equiseti & C12 & - & AY147368 \\
\hline F. equiseti & D & Soil & KT634075 \\
\hline F. equiseti & FE9 & Oryza sativa & HQ995668 \\
\hline F. equiseti & MGSS 138 & Carica papaya -Fruit & MF449219 \\
\hline F. guttiforme & NRRL 22945 & - & U34562 \\
\hline Fusarium hostae & DAOMC235655 & - & KR909426 \\
\hline Fusarium longipes & DEB13 & Soil & KF918597 \\
\hline F. longipes & BCCM/IHEM 18093 & Soil & KJ125587 \\
\hline Fusarium oxysporum & - & Soil & EF017214 \\
\hline F. oxysporum & KP10 & Pynus sylvestris & DQ093759 \\
\hline F. oxysporum & PARC682c & Prunus avium & KT455376 \\
\hline F. oxysporum & MGSS 42 & Solanum Iycopersicon-Vascular System & MF449220 \\
\hline F. oxysporum & MGSS 14 & Heliconia sp.- Vascular System & MF449210 \\
\hline F. oxysporum & MGSS 182 & S. Iycopersicon-Vascular System & MF449207 \\
\hline F. oxysporum & MGSS 183 & S. lycopersicon-Vascular System & MF449199 \\
\hline F. oxysporum & MGSS 15 & Ananas comosus - plant base & MF449197 \\
\hline F. oxysporum & MGSS 09 & Musa sp.- Vascular System & MF449193 \\
\hline F. oxysporum & MGSS 118 & Coriandrum sativum - Sistema vascular & MF449190 \\
\hline F. oxysporum f. sp. Cubense & $115 \mathrm{HT}$ & - & EF155534 \\
\hline F. oxysporumf. sp. Iycopersici & FO29 & S.lycopersicum & KF914468 \\
\hline Fusarium guttiforme & MGSS 68 & A.comosus- fruit & MF449192 \\
\hline F. guttiforme & MGSS 54 & A.comosus - plant base & MF449201 \\
\hline F. proliferatum & MGSS 61 & Aleurocanthus woglumi & MF449213 \\
\hline Fusarium sp. (Gibberella fujikuroi complex) & MGSS 141 & Hibiscus sabdariffa - stalk & MF449217 \\
\hline Fusarium sp. (Gibberella fujikuroi complex) & MGSS 157 & H.sabdariffa - stalk & MF449221 \\
\hline F. proliferatum & NRRL 31071 & Triticum aestivum & AF291061 \\
\hline F. proliferatum & UTcp8 & Vigna unguiculata & КT376487 \\
\hline F proliferatum & D2 & Zea mays & EU151485 \\
\hline Fusarium phyllophilum & PEN6 & Vitis sp. & KR909206 \\
\hline Fusarium pseudocircinatum & ATCC MYA-4835 & - & JQ070125 \\
\hline F. sterilihyposum & MRC7602 & - & AF430130 \\
\hline F. sterilihyposum & MRC7602 & - & AF430130 \\
\hline F. sterilihyposum & MRC7602 & - & AF430130 \\
\hline F. subglutinans & - & Zea mays & X94167 \\
\hline Fusarium sp. & MC-23-F NRRL125184 & Monarda citriodora & KU527804 \\
\hline F. lateritium & - & Rosa sp. & AY904057 \\
\hline F. verticilloides & - & Zea mays & X94166 \\
\hline F. verticilloides & JJTKCL & Saccharum officinarum & KJ544799 \\
\hline Fusarium sacchari & NRRL 43543 & - & EF453121 \\
\hline F. sacchari & ATCC 201263 & - & KR909411 \\
\hline Lecanicillium lecanii & CBS122175 & Hylurgops palliatus & DQ449654 \\
\hline Microdochium nivale & MTCC 6580 & - & JN642711 \\
\hline
\end{tabular}

${ }^{1}$ The 14 sequences in bold were obtained from the present study and registered in the Genbank. 


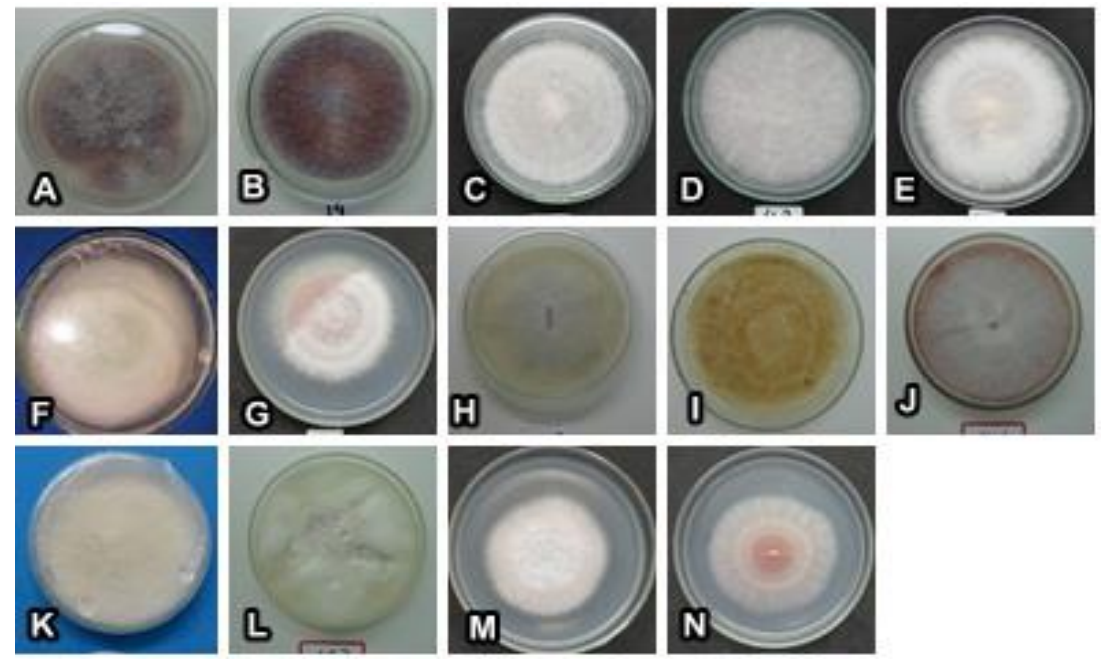

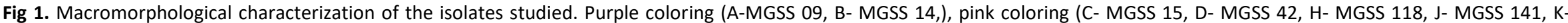
MGSS 149, M-MGSS 182, N-MGSS 183), salmon coloring (F- MGSS 61), pink coloring with pale borders (E- MGSS 54, G- MGSS 68, L- MGSS 157) burnt yellow coloring (I- MGSS 138).

Table 2. Fusarium spp. macro and micromorphological characteristics.

\begin{tabular}{|c|c|c|c|c|c|c|c|c|c|}
\hline \multirow[t]{4}{*}{ MGSS } & \multicolumn{9}{|l|}{ MORPHOLOGICAL ASPECTS } \\
\hline & \multirow{3}{*}{$\begin{array}{l}\text { MACROSCOPIC } \\
\text { COLOR }\end{array}$} & \multicolumn{8}{|l|}{ MICROSCOPIC } \\
\hline & & \multicolumn{2}{|l|}{ MICROCONIDIA } & \multirow[t]{2}{*}{ PHIALIDES } & \multirow[t]{2}{*}{ CHLAMYDOSPORES } & \multicolumn{2}{|c|}{ MACROCONIDIA } & \multicolumn{2}{|c|}{ MESOCONIDIA } \\
\hline & & SHAPE & $\begin{array}{l}\text { NUMBER OF } \\
\text { SEPTA }\end{array}$ & & & SHAPE & $\begin{array}{l}\text { NUMBER OF } \\
\text { SEPTA }\end{array}$ & SHAPE & $\begin{array}{l}\text { NUMBER OF } \\
\text { SEPTA }\end{array}$ \\
\hline 09 & Purple coloring & Oval & 0 & Short monophialides & - & Allantoid & 3-5 & - & - \\
\hline 14 & Purple coloring & Oval & $0-1$ & Short monophialides & - & Allantoid & 3-5 & - & - \\
\hline 15 & Pink coloring & Oval & 1 & Short monophialides & Individual & Allantoid & 3-5 & - & - \\
\hline 42 & Pink coloring & Oval & $0-1$ & Short monophialides & Individual and in pairs & Allantoid & 3-5 & - & - \\
\hline 54 & Pink coloring with pale borders & Oval and obovoid & $0-1$ & Monophialides and poly phialides & - & Allantoid & 3-5 & - & - \\
\hline 61 & Salmon coloring & Oval & 1 & Monophialides and poly phialides & - & Allantoid & 3-5 & - & - \\
\hline-68 & Pink coloring with pale borders & Oval & $0-2$ & Monophialides and poly phialides & - & Allantoid & $2-5$ & - & - \\
\hline 118 & Pink coloring & Oval & $0-1$ & Short monophialides & - & Allantoid & 3-5 & - & - \\
\hline 138 & Burnt yellow coloring & - & - & Monophialides & Individual & Allantoid & $5-7$ & - & - \\
\hline 141 & Pink coloring & Oval & 1 & Monophialides and poly phialides & - & Absent & - & - & - \\
\hline 149 & Pink coloring & - & - & Monophialides & Individual & Allantoid & $5-7$ & Elliptic & $1-2$ \\
\hline 157 & Pink coloring with pale borders & Oval & 0 & Monophialides and poly phialides & - & Absent & - & - & - \\
\hline 182 & Pink coloring & Oval & 1 & Short monophialides & clustered or in short chains & Allantoid & 3-5 & - & - \\
\hline 183 & Pink coloring & Oval & 1 & Short monophialides & Individual & Allantoid & 3-5 & - & - \\
\hline
\end{tabular}




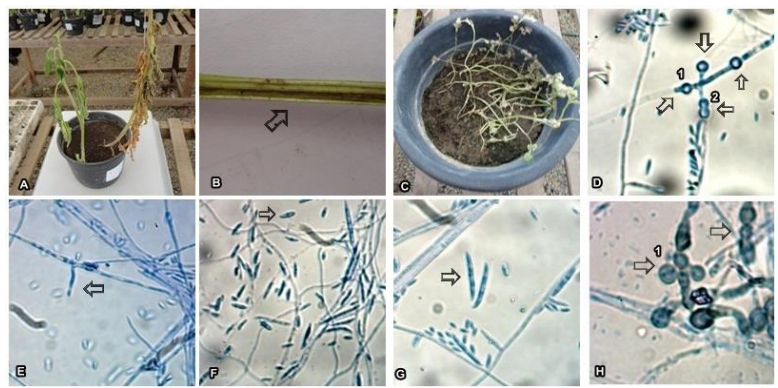

Fig 2. Morphological characteristics and typical symptoms of the species $F$. oxysporum observed in isolates obtained in the present study. A - fusarium wilt in tomato (MGSS 183), B- Vascular darkening (MGSS 182), C- fusarium wilt in Coriandrum sativum (MGSS 118), D- Chlamydospores 1(individual) and 2 ( in pairs) (MGSS 42), short E- Monophialide curta (MGSS 09), F- Microconidia (MGSS 14), G- Macroconidia 3-5 septa (MGSS 42), H- Chlamydospores 1 (clustered) (MGSS 182).

Table 3. Association between morphological characterization of the isolates and symptomological aspects caused in the respective hosts.

\begin{tabular}{|c|c|c|c|c|}
\hline \multirow[t]{2}{*}{ MGSS } & \multicolumn{2}{|l|}{ Symptomatological Aspects } & \multicolumn{2}{|c|}{ Morphological Classification } \\
\hline & Pathogen Isolation Place & Symptoms & Section $^{1}$ & Species Complex \\
\hline 09 & Vascular system & Wilt & Elegans & FOSC \\
\hline 14 & Vascular system & Wilt & Elegans & FOSC \\
\hline 15 & Plant base & Exudation & Elegans & FOSC \\
\hline 42 & Vascular system & Wilt & Elegans & FOSC \\
\hline 54 & Plant base & Exudation of gum. & Liseola & GFSC \\
\hline 61 & Insect & Colonization of nymphs & Liseola & GFSC \\
\hline 68 & Fruit & Exudation of gum & Liseola & GFSC \\
\hline 118 & Vascular system & Wilt & Elegans & FOSC \\
\hline 141 & Stalk & Stem rot & Liseola & GFSC \\
\hline 138 & Fruit & Fruit rot & Gibbosum & FIESC \\
\hline 149 & Leaf & Leaf Rot & Gibbosum & FIESC \\
\hline 157 & Stalk & Stem rot & Liseola & GFSC \\
\hline 182 & Vascular system & Wilt & Elegans & FOSC \\
\hline 183 & Vascular system & Wilt & Elegans & FOSC \\
\hline
\end{tabular}
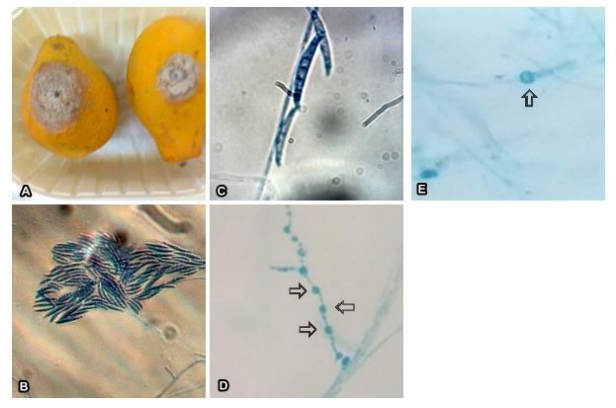

Fig 3. Morphological characteristics and symptoms associated to isolates belonging to the Gibbosum section A - rot in Carica papaya fruit (MGSS 138), B - Macroconidi abundance (MGSS 149), C - Macroconidia with dorsoventral curve (MGSS 138), D- Arrows indicate chlamydospores (MGSS 138) and E - Arrows indicate individual chlamydospore (MGSS 149).

Table 4. Isolates used in the morphological and molecular characterization

\begin{tabular}{|lll|}
\hline Code & Host & $\begin{array}{l}\text { Year of Registration in the MGSS } \\
\text { Fungi Collection }\end{array}$ \\
\hline MGSS 09 & Musa sp. & 2011 \\
\hline MGSS 14 & Heliconia sp. & 2011 \\
\hline MGSS 15 & Ananas comosus & 2011 \\
\hline MGSS 42 & Solanum lycopersicon & 2012 \\
\hline MGSS 54 & A. comosus & 2012 \\
\hline MGSS 61 & Aleurocanthus woglumi & 2012 \\
\hline MGSS 68 & A. comosus & 2012 \\
\hline MGSS 118 & Coriandrum sativum & 2014 \\
\hline MGSS 138 & Carica papaya & 2014 \\
\hline MGSS 141 & Hibiscus sabdariffa & 2014 \\
\hline MGSS 149 & Lactuca sativa & 2014 \\
\hline MGSS 157 & H. sabdariffa & 2014 \\
\hline MGSS 182 & S. Iycopersicon & 2014 \\
\hline MGSS 183 & S. lycopersicon & 2014 \\
\hline
\end{tabular}

${ }^{1}$ MGSS - Micoteca Prof. Gilson Soares da Silva. 


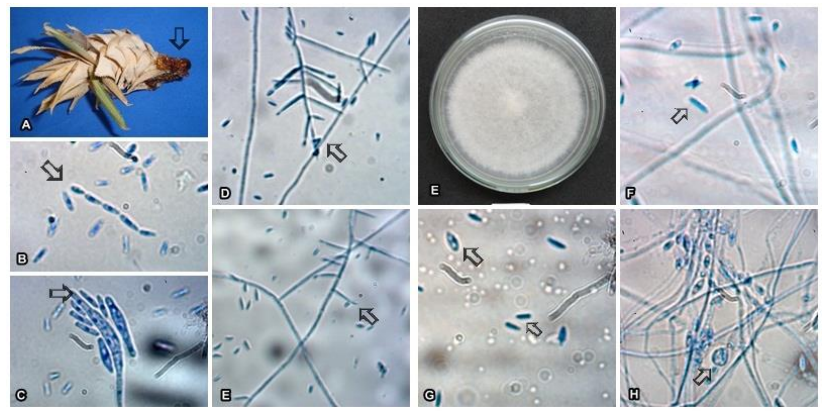

Fig 4. Morphological characteristics and typical symptoms of $F$. guttiforme associated to A. comosus. A. Plant base with gum exudation (MGSS 54 ), BMicroconidia chain (MGSS 68), C- Macroconidia (MGSS 68), D- Polyphialides (MGSS 54), E- Monophialide (MGSS 54). Isolate MGSS 15 (E-G) common characteristics between F. guttiforme and F. oxysporum (H) characteristic that excludes it from F. guttiforme. E- Colony, F-G- Microconida and HChlamydospores.

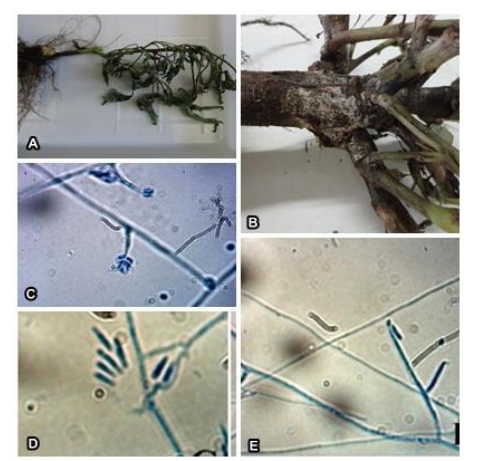

Fig 5. Characteristics of the isolates belonging to the Liseola section. A and B- Rot in H. sabdariffa roots. C- Short monophialide curta and false head formation (MGSS 141), D- Microconidia (MGSS 157) , E-Polyphialide (MGSS 157).

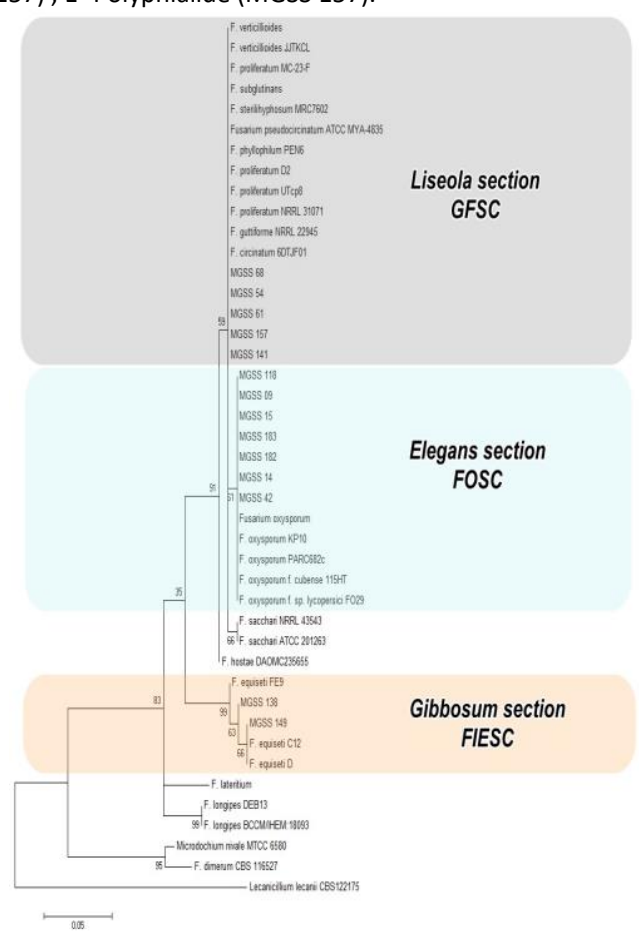

Fig 6. Phylogenetic tree by the Maximum Likelihood method (ML) based on the Jukes-Cantor model derivates of the gene ITS for the genus Fusarium. The consensus bootstrap tree inferred from 1000 replications. Lecanicillium lecanii Q449654 was used as outgroup.

Research on $F$. oxysporum phylogeny indicates that there is a larger complexity in the evolutionary history of this species regarding its formae speciales. Epstein et al. (2017) observed that out of 12 isolates of $F$. oxysporum f. sp. apii race 2 are more directly related to $F$. oxysporum f. sp. lycopersici race 2 and $F$. oxysporum f. sp. melonis clustered in clade 3 and this performance can be explained due to the polyphylectic nature. Nirmaladevi et al. 2016 also concluded the polyphyletic nature 
of $F$. oxysporum f. sp. lycopersici based on sequences from the ITS region. These results confirmed our findings, where all the different formae speciales formed a single group in the phylogenetic analysis.

The nature or symptoms of the disease give important clues regarding the probable species responsible for the disease in these hosts and often limit the range of species that should be distinguished (Leslie and Summerell, 2006). In the present study, the fungi isolated from plants with symptoms of vascular darkening and severe wilt were classified both morphologically and phylogenetically as belonging to $F$. oxysporum Schlechtendal. The isolates obtained from the following pathogen systems: S. lycopersicon/vascular darkening (MGSS 42, MGSS 182, MGSS 183); Heliconia sp./ vascular darkening (MGSS 14); Musa sp./ vascular darkening (MGSS 09); C. sativum/ vascular darkening (MGSS 118); $A$. comosus/gummosis (MGSS 15).

Of the pathogen systems mentioned above, the morphological and molecular classification of the isolate MGSS 15 that was obtained from $A$. comosus was surprising because in Brazil fusariosis in $A$. comosus has been reported by several authors (Carnielli-Queiroz, 2019; Ventura and Góes, 2016) with F. guttiforme as causal agent. However, this isolate was identified as $F$. oxysporum according to the morphological characteristics and the phylogeny of the ITS gene. The results showed that more than one species is the causal agent of fusariosis in this host; Vásquez-Jiménez and Mata-Granados (2014); Stepień et al. (2013) also reported the occurrence of $F$. oxysporum in $A$. comosus crops in Costa Rica, Vietnam and Ecuador causing different forms of rot in this host.

The G. fujikuroi species complex (GFSC) encompasses monophylectic taxon in a set of Fusarium species with similar morphological and overlaid characteristics. This complicates their differentiation at species level. A large part of this species is associated with devastating diseases in several economically important plants (Kvas et al., 2009) and pathogenic to insects (Pelizza et al., 2011; Sharma et al, 2018).

The isolates that were morphologically classified within the (GFSC) species complex were also grouped in the same complex by characterization of the ITS region of the ribosomal DNA, indicating that this region of the DNA is very useful to identify species complex of the genus, a result also reported by Al-Hatmi et al. (2016).

Although the ITS region combines the highest power of resolution to discriminate closely related species and successful sequencing in a wide variety of fungi (Schoch et al., 2012), the phylogeny of species within this complex (GFSC) is difficult to define using only the gene of the ITS region (Al-Hatmi et al., 2016; O'Donnell et al., 2015; Schoch et al., 2012). Our results confirm that the phylogenetic evolution for information at species level through the ribosomal DNA ITS region is not enough for the sequences belonging to the $G$. fujikuroi species complex (GFSC) and the use of multiple genes is more suggested by authors (Kvas et al., 2009) and (Leyva-Madrigal et al., 2015).

\section{Materials and Methods}

\section{Experimental location and obtaining Fusarium isolates}

The experiments were carried out in the Plant Pathology Laboratory of the Agricultural Biotechnology Nucleus Genetic
Laboratory- Labwick University Campus Paulo VI, São Luís MA, Brazil and the Genetics and Molecular Biology Laboratory at the State University of Maranhão - UEMA, Caxias Center Campus of Higher Studies - CESC, Caxias -MA, Brazil.

The isolates were obtained from the "Prof. ${ }^{\circ}$ Gilson Soares da Silva" Library at the State University of Maranhão - UEMA, University Campus Paulo VI, São Luís - MA, Brazil, and conserved in the continuous replication method (Table 4).

\section{Morphological characterization of the Fusarium spp. isolates} The isolates were placed to grow on monospore cultures and to classify the colonies for color, macroconidia, microconidia and chlamydospores. Microcultures were also made to observe the fungi structures under an optical microscope for later photographic registration by AxioCam model ERc $5 \mathrm{~s}$ (ZEISS ${ }^{\circledR}$ ). The keys were the Genus Fusarium (Booth, 1971), the Fusarium Laboratory Manual (Leslie and Summerell, 2006) and Fusarium species. An Illustrated manual for identification (Nelson et al., 1983) were used to identify the isolates. The isolates were grouped in species sections and complexes associated to the sites of isolation and symptoms in the hosts.

\section{Molecular characterization characterization of the Fusarium} isolate

\section{DNA extraction and amplification of the rDNA ITS region}

The genomic DNA was extracted using the KIT HiPuraTM (Himedia ${ }^{\circledR}$ ). The samples were prepared for extraction by culturing the isolate in solid medium and later scraping. After obtaining the samples, about $100 \mathrm{mg}$ fungus tissue were squashed in the presence of liquid nitrogen to form a fine powder and then DNA was extracted according the extraction protocol supplied together with the kit.

An aliquot was removed from the samples of the extracted DNA to verify the DNA quality and concentration by comparative analysis in $0.9 \%$ agarose gel containing ECG and ethidium bromide at $0.01 \%(\mathrm{~V} / \mathrm{V})$. After this process the samples were stored at $-80^{\circ} \mathrm{C}$ until use.

The ITS1-5.8S-ITS2 regions of the ribosomal DNA (rDNA) were amplified following methodology described by White et al. (1990) using the primers ITS1 (5'-TCCGTAGGTGAACCTGCGG-3') and ITS4 (5-'TCCTCCGCTTATTGATATGC-3') in a thermocycler programmed for the following conditions: $94{ }^{\circ} \mathrm{C}$ for 12 minutes (denaturation and enzymatic activation), 35 cycles $-94 \% \mathrm{C}$ for 30 seconds (denaturation), 55으 for 30 seconds (aneling) and $72 \circ \mathrm{C}$ for 30 seconds (extension), 72ㅇ for 10 minutes (final extension). For the PCR reaction were used $20 \mathrm{ng}$ DNA molde, $10 \mathrm{mM}$ each primer, $1.5 \mathrm{mM}$ and $\mathrm{MgCl}_{2}, 0.08 \mathrm{mM}$ of each dNTP, $02 \mathrm{U} / \mu \mathrm{L}$ Taq DNA polymerase, $50 \mathrm{mM}$ Tris- $\mathrm{HCl}(\mathrm{pH} 8.4)$ and $20 \mathrm{mM} \mathrm{KCl}$ in $50 \mu \mathrm{L}$ final volume. An aliquot of the amplification reaction product $(10 \mu \mathrm{L})$ was submitted to electrophoresis in $1.5 \%(\mathrm{p} / \mathrm{v})$ agarose gel in TBE $1 \mathrm{X}$ buffer containing ethidium bromide at a concentration of $0.01 \%$ $(\mathrm{v} / \mathrm{v})$, at $90 \mathrm{~V}$ for one hour. The Scada $100 \mathrm{bp}$ DNA Ladder (Sinapse inc.) was used as molecular weight marker. After electrophoresis, the gel was removed from the cube and visualized under UV light and then photographed.

The products of the PCR reaction were purified using commercial kits of purification by column (Purelink ${ }^{\circledR}$ - Thermo Fisher Scientific, Inc.), and were sent for sequencing in the Genetics and Molecular Biology Laboratory of the State 
University of Maranhão (Campus CESC, Caxias - MA, Brazil). The consensus sequences generated were compared with those deposited in the $\mathrm{NCBI}$ databank (National Centre for Biotechnology Information website -http://www.ncbi.nlm.nih.gov), using the BLAST search tool to confirm the genus of each one of the isolates.

\section{Phylogenetic analyses of the genus Fusarium isolates}

The phylogenetic analyses were carried out using the MEGA 6 program (Tamura et al., 2013). The sequences were aligned using the CLUSTALW implemented by the MEGA 6 and adjusted to the Jukes-Cantor model. The Maximum Likelihood phylogenetic trees and the significance of the groupings of the phylogenetic trees were estimated by 1000 bootstrap replications and comparison to the other sequences deposited in the GenBank (Bioproject PRJNA730933) (http://www.ncbi.nlm.nih.gov/genbank/), and /or type-species present (Table 1).

\section{Conclusion}

All the isolates classified morphologically as Fusarium oxysporum also presented phylogenetic relationships with strains belonging to the same species. Two of the three isolates obtained from $A$. comosus with gummosis symptoms. The isolates MGSS54 and MGSS 68 were classified morphologically as $F$. guttiforme and molecularly belonged to (GFSC) and one isolate MGSS 15 was classified as F. oxysporum (FOSC), confirming that two species are responsible for the diseases in this host. The isolates classified morphologically within the Gibberella fujikuroi species complex (GFSC) were presented evolutionary by the ITS rDNA gene within clades with species belonging to the same species complex. However, there was no species definition indicating an analysis with multiple loci for better elucidation of the species. Two isolates MGSS 138 and MGSS 149 classified morphologically in the Gibbosum section in the $F$. incarnatum-equiseti species complex (FIESC) presented evolutionary history through the rDNA ITS gene grouping in the $F$. equiseti species.

\section{Acknowledgements}

The authors thank the Fundação de Amparo à Pesquisa e ao Desenvolvimento Científico e Tecnológico do Maranhão (FAPEMA); the State University of Maranhão; à Coordenação de Aperfeiçoamento de Pessoal de Nível Superior (CAPES); the researcher Maria Claudene Barros.

\section{References}

Agbenin ON, Ogunlan, MO (2006) Occurrence of Fusarium Wilt and Nematodes on Red Calyx Roselle (Hibiscus Sabdariffa L.) in Northern Nigeria. J Plant Prot Res. 46: 117-121.

Akbar A et al. (2018) Detection, virulence and genetic diversity of Fusarium species infecting tomato in Northern Pakistan. PLoS One. 13: 1-21.

Al-Hatmi, AMS et al. (2019) Multiresistant Fusarium Pathogens on Plants and Humans: Solutions in (from) the Antifungal Pipeline? Infection and Drug Resistance. 12:3727-3737.

Al-Hatmi AMS et al. (2016) Evaluation of two novel barcodes for species recognition of opportunistic pathogens in
Fusarium. Fungal Biol. 120: 231-245.

Amusa NA et al. (2005) Vascular Wilt of Roselle (Hibiscus sabdariffa L. var. sabdariffa) in the Humid Forest Region of South-western Nigeria. Plant Pathol J. 4:122-125.

Aoki T et al. (2014) Systematics of key phytopathogenic Fusarium species: Current status and future challenges. J. Gen. Plant Pathol. 80: 189-201.

Aoki T et al. (2019) Three novel Ambrosia Fusarium Clade species producing clavate macroconidia known (F. floridanum and $F$. obliquiseptatum) or predicted ( $F$. tuaranense) to be farmed by Euwallacea spp. (Coleoptera: Scolytinae) on woody hosts. Mycologia. 11:1-17.

Bonde SR et al. (2014) Genetic Variations among Ten Isolates of Fusarium equiseti ( Corda ) Saccardo Isolated from Fruits and Vegetables. Austin J Biotechnol Bioeng. 1: 1-5.

Booth C (1971) The Genus Fusarium. Commonwealth Mycological Institute, Kew.

Carnielli-Queiroz L et al. (2019) A Rapid and Reliable Method for Molecular Detection of Fusarium guttiforme, the Etiological Agent of Pineapple Fusariosis Brazilian Archives of Biology and Technology. 62: 1-11.

Castellá G, Cabañes FJ (2014) Phylogenetic diversity of Fusarium incarnatum-equiseti species complex isolated from Spanish wheat. Antonie van Leeuwenhoek., Int J Gen Mol Microbiol. 106: 309-317.

Choi H W et al (2018) Taxonomy of Fusarium fujikuroi species complex associated with bakanae on rice in Korea. Australasian Plant Pathology. 47: 23-34. Epstein L, et al (2017) Races of the celery pathogen fusarium oxysporum $f$. sp. Apii are polyphyletic. Phytopathology.107: 463-473.

Figueroa-rivera M G et al (2010) Caracterización de Especies de Fusarium Asociadas a la Pudrición de Raíz de Maíz en Guanajuato, México. Rev Mex Fitopatol. 28:124-134.

Fischer I H, Rezende J A M (2016) Doenças do Maracujazeiro.In: Amorim, L., Rezende, J.A.M., Bergamin Filho, A., Camargo, L.E.A. (Eds.). Manual de Fitopatologia: Doenças Das Plantas Cultivadas. Agronômica Ceres, Ouro Fino, pp. 535-543.

Fourie $\mathrm{G}$ et al (2011) Current status of the taxonomic position of Fusarium oxysporum formae specialis cubense within the Fusarium oxysporum complex. Infect Genet Evol. 11: 533542.

Hassan N et al (2014) Occurrence of root rot and vascular wilt diseases in roselle (Hibiscus sabdariffa L .) in upper Egypt. Mycobiology. 42: 66-72.

Hsuan HM et al (2011) Molecular identificationn of Fusarium species in gibberella fujikuroi species complex from rice, sugarcane and maize from Peninsular Malaysia. Int J Mol Sci. 12: 6722-6732.

Imazaki I, Kadota I (2015) Molecular phylogeny and diversity of Fusarium endophytes isolated from tomato stems. FEMS Microbiol Ecol. 91: 1-16.

Kvas M et al. (2009) Diversity and evolution of Fusarium species in the Gibberella fujikuroi complex. Fungal Divers. 34: $1-21$.

Leslie JF, Summerell BA (2006) The Fusarium Laboratory Manual, 1st ed. Blackwell Publishing, lowa.

Leyva-Madrigal KY et al. (2015) Fusarium Species from the Fusarium fujikuroi Species Complex Involved in Mixed Infections of Maize in Northern Sinaloa, Mexico. J Phytopathol. 163: 486-497. 
Maryani N et al. (2019) New endemic Fusarium species hitch-hiking with pathogenic Fusarium strains causing Panama disease in small-holder banana plots in Indonesia. Persoonia. 43: 48-69.

Moussa TAA et al. (2017) Two new species of the Fusarium fujikuroi species complex isolated from the natural environment. Antonie Van Leeuwenhoek. 110: 819-832.

Nadarajah $\mathrm{K}$ et al. (2015) The host pathogen interactions observed between Fusarium sp. F2 and rice. Plant Omics. 8: 572-580.

Nayaka SC et al. (2009) Control of Fusarium verticillioides, cause of ear rot of maize, by Pseudomonas fluorescens. Pest Manag. Sci. 65: 769-775.

Nelson PE et al. (1983) Fusarim species:An illustrated manual for identification. Pennsylvania State University Press, University Park.

Nirmaladevi D et al. (2016) Molecular phylogeny, pathogenicity and toxigenicity of Fusarium oxysporum f. sp. lycopersici. Sci. Rep. 6: 1-14

O'Donnell K et al. (2018) Marasas et al. 1984 "Toxigenic Fusarium Species: Identity and Mycotoxicology" revisited. Mycologia. 27:1058-1080.

O'Donnell K et al. (2016) Veterinary fusarioses within the United States. J Clin Microbiol. 54:2813-2819.

O'Donnell K et al. (2013) Phylogenetic analyses of RPB1 and RPB2 support a middle Cretaceous origin for a clade comprising all agriculturally and medically important fusaria. Fungal Genet. Biol. 52: 20-31.

O'Donnell K et al. (2015) DNA sequence-based identification of Fusarium: Current status and future directions. Phytoparasitica. 43: 583-595.

Papizadeh $M$ et al. (2018) Fusarium ershadii sp. nov., a pathogen on Asparagus officinalis and Musa acuminata. Eur. J. Plant Pathol. 151:689-701.

Pelizza S A et al. (2011) First record of Fusarium verticillioides as an entomopathogenic fungus of grasshoppers. J. Insect Sci. 11:1-8.

Ramdial $\mathrm{H}$ et al. (2017) Phylogeny and haplotype analysis of fungi within the Fusarium incarnatum-equiseti species complex. Phytopathology. 107: 109-120.
Sandoval-Denis M et al. (2018) Symptomatic Citrus trees reveal a new pathogenic lineage in Fusarium and two new Neocosmospora species Persoonia. 40: 1-25.

Santos ACS et al. (2019) Entomopathogenic Fusarium species: a review of their potential for the biological control of insects, implications and prospects, Fungal Biology Reviews.1-17.

Schoch CL et al. (2012) Nuclear ribosomal internal transcribed spacer (ITS) region as a universal DNA barcode marker for Fungi. Proc Natl Acad Sci. U. S. A. 109: 6241-6246.

Sharma $L$ et al (2018) Insect-associated fungi from naturally mycosed vine mealybug Planococcus ficus (Signoret) (Hemiptera: Pseudococcidae). Biocontrol Science and Technology., 28:2, 122-141.

Stepień $\measuredangle$ et al (2013) Diversity of Fusarium species and mycotoxins contaminating pineapple. J Appl Genet. 54: 367380.

Summerell B A (2019) Resolving Fusarium: Current Status of the Genus. Annu Rev Phytopathol. 57:323-339.

Tamura K et al (2013) MEGA6: Molecular Evolutionary Genetics Analysis version 6.0. Mol. Biol. Evol. 30: 2725-2729.

Teixeira L M et al (2017) Characterization of Fusarium oxysporum Isolates and Resistance of Passion Fruit Genotypes to Fusariosis. Rev Bras Frutic. 39: 1-11.

Van Diepeningen A D, Hoog G S (2016) Challenges in Fusarium, a Trans-Kingdom Pathogen. Mycopathologia. 181:161-163

Vásquez-Jiménez J, Mata-Granados X (2014) Diagnosis of Fusarium oxysporum in the cultivation of pineapple Ananas comosus (L) Merr. Net J Agric Sci. 2: 107-112.

Ventura J A, Góes A (2016) Doenças do Abacaxi. In: Amorim, L., Rezende, J.A.M., Bergamin Filho, A., Camargo, L.E.A. (Eds.), Manual de Fitopatologia: Doenças Das Plantas Cultivadas. Agronômica Ceres, Ouro Fino, pp. 9-16.

White T J et al (1990) Amplification and Direct Sequencing of Fungal Ribosomal Rna Genes for Phylogenetics. PCR Protoc. 315-322.

Yuan L et al (2013) Genetic diversity and structure of the Fusarium oxysporum f.sp. lini populations on linseed (Linum usitatissimum) in China. Phytoparasitica. 41: 391-401.

Zarrin M et al (2016) Analysis of the rDNA internal transcribed spacer region of the Fusarium species by polymerase chain reaction-restriction fragment length polymorphism. Biomed Reports. 4: 471-474. 